\title{
A Categoria Espaço na Teoria Social
}

\author{
Maria Tereza D.P. Luchiari
}

RESUMo: Este artigo é um mapeamento preliminar de importantes contribuições, no campo das Ciências Humanas, para a compreensão da categoria espacial - enquanto objeto de ciência e instrumento analítico - no contexto da sistematização do pensamento científico e de algumas "visões de mundo" que orientaram o projeto da modernidade e seus desdobramentos contemporâneos.

UNITERMOS: Espaço, tempo, modernidade, globalização, ambiente, tcoria social.

\section{APRESENTAÇÃo}

Este texto é um mapeamento preliminar de algumas contribuições importantes, no campo das Ciências Humanas, para a compreensão da categoria espacial - enquanto objeto de ciência e referência metodológica - no contexto da sistematização do pensamento científico e de algumas visões de mundo" que orientaram o projeto da modernidade e seus desdobramentos contemporâneos.

Partindo da concepção iluminista de "progresso" é possível compreender como a metáfora do tempo predominou na mentalidade de uma sociedade que buscava sua constante superação. Desta forma, espaço e natureza foram manipulados por uma racionalidade instrumental que atribuiu ao tempo o devir de uma nova sociedade. 
Também a teoria social, orientada pelo historicismo, transformou o espaço no palco inerte onde os atores sociais desenrolam suas ações. Mas quando a perspectiva espacial parecia estar fadada ao descaso, algumas vozes se levantaram reivindicando uma teoria social que nào desse preponderância ao tempo, mas buscasse um equilíbrio interpretativo entre tempo e espaço ou, entre história, geografia e sociedade.

A década de setenta torna-se um marco privilegiado deste debate. Autores de vários campos científicos somam suas vozes para criticar os efeitos perversos da modernidade, e lembrar da importância da análise espacial que, marginalizada da teoria social, foi um instrumento de dominação e poder muito bem articulado pelo Estado e pela economia capitalista.

Somando-se a essas vozes, a emergência da problemática ambiental, a globalizaçào da economia e a mundializaçào da cultura trouxeram de volta à cena contemporânca um repensar a relação entre sociedade, natureza $\mathrm{e}$ território a partir dos "modelos de desenvolvimento". Neste sentido, o espaço como categoria analítica torna-se um instrumento interpretativo de fundamental importância para a compreensão da realidade e para o avanço no processo do conhecimento científico.

\section{Do Conceitual À REALIDADE}

No espaço e no tempo as sociedades se articulam e se organizam de formas diferenciadas. No espaço, elas se inscrevem criando lugares singulares, produtos de desenvolvimentos e processos sociais desiguais. No tempo, observam-se processos de desenvolvimento das sociedades, às vezes sucessivos e sincrônicos, outras vezes em descompasso em relação ao espaço e sociedades globais.

Ao longo da história da humanidade o homem buscou formas de se desenvolver. Viveu em bandos, em tribos, em sociedade... Acelerou o processo de obtenção de conhecimento e de bens materiais fazendo deste pro- 
cesso um modelo de desenvolvimento. Mas o que é desenvolvimento? Os conceitos de progresso, desenvolvimento e evoluçào foram muitas vezes confundidos na história do homem. Conceitos que, a princípio, poderiam orientar uma visào otimista sobre o futuro acabaram transformando-se numa teia complexa para a ciência, para o Estado e para a sociedade.

A natureza do progresso, sua linearidade, seus elementos constitutivos preocuparam durante muitos séculos pensadores que tentaram identificar uma unidade na diversidade espaço-temporal de suas formas.

" $A$ idéia de progresso - esse conjunto de reflexões cuja expressão clássica se cncontra em Aristóteles e Agostinho, em Fontenelle e Saint-Pierre, em Condorcet e Comte, em Spencer e Taylor encerra uma imagem detalhada c abrangente de mudança". (Bottomore \& Nisbet, 1980, p.67)

A centralidade da idéia de evoluçào humana imprimiu um traço característico ao projeto civilizatório. Desde a Antigüidade o antropocentrismo já era um sentimento arraigado: tudo havia sido criado para o bem estar e prazer do homem, inclusive a natureza. A Bíblia e a "leitura de mundo" dos filósofos clássicos como Aristótcles, Descartes, Locke e Bacon sustentaram esta concepçào. A noçào de "civilizaçào humana" estava profundamente amarrada à "conquista da natureza". Com o Renascimento e a Revolução Científica nascente o homem passou a louvar a si mesmo como o criador, senhor da "razão" e da natureza e, da mesma forma, passou a manipular tempo e espaço em função do seu projeto de modernidade.

Para Habermas (1980) o termo "modernidade" sempre se fez presente quando uma época queria ultrapassar um divisor de águas em relação à Antigüidade. Isto faz sentido tanto com o Renascimento dos séculos XV e XVI - que buscava na arte e na ciência um retorno a Antigüidade Clássica, como para o Iluminismo do século XIX a partir do qual a Europa se colocou frente a frente à Antigüidade na busca do progresso, da razão e da liberdade de pensamento em oposição à tradição e à autoridade. 
O moderno passou a ser o novo em constante atualização. Nas entrelinhas, o clássico se mantém presente não mais como um passado recuperado mas como um presente constantemente superado. Em oposição ao tempo clássico que sobrevivia aos tempos, a metáfora tempo é revista em sua espirituosidade e capacidade de renovação. É esta capacidade da modernidade em criar o seu próprio classicismo que é concebida como destruidora e produtiva.

Esta modernidade renovada sob a inspiraçào da arte e da ciência passou a ver o espaço como um território desconhecido a ser explorado, e o tempo como o transitório, efêmero, fugaz tanto na experiência da mobilidade social, da aceleração da história ${ }^{1}$ como do cotidiano descontínuo.

É com este espírito que, no século XIX, o "progresso" passou a ser o carro-chefe do capitalismo em ascensão, e as sociedades tradicionais/primitivas foram vistas como retardatárias em uma escala de evolução onde a sociedade industrial européia se encontrava no estágio mais avançado. Na verdade, as diferenças culturais sempre se constituíram em um problema para a perspectiva do progresso, e o modelo desenvolvimentista europeu logo configurou-se como etnocêntrico. Neste contexto, a colonizaçào, a cristianização do Novo Mundo, a cientifização c a civilização dos selvagens e suas selvas representaram tentativas de homogencização, enquanto eliminaçào das diferenças. Como sugerem Horkheimer \& Adorno (1969), o Iluminismo é refém do sistema, da razão que tudo ordena, da unidade que tudo controla - uniformidade lógica.

A idéia de progresso, como uma seqüencia linear e evolutiva, associou-se à racionalidade científica e tecnológica através da qual o homem

'Habermas se refere à arte e à estética nas correntes de vanguarda quando afirma que à profanação de toda normatividade se aliou a vontade de destruir o continuo da história. Esta consciência estética reuniu o antitradicionalismo a esta oposição abstrata à história. Mas, mesmo neste caso, Habermas afirma que esta oposição foi, na verdade, uma postura crítica à falsa normatividade de uma compreensão da história inspirada na imitação de modelos e no historicismo de muscus, embora, segundo ele, a compreensão da história não tenha sido eliminada nem da hermenêutica de Gadamer. 
ocidental se tornaria cada vez mais poderoso. A ciência empírica e metódica substituiu o mistério, a superstição, a intuição; mas foi tão dura com os homens que quebrou o encantamento com o mundo. Enquanto a ciência objetiva se desenvolvia, a idéia moderna de progresso se dissociava da visão da boa sociedade.

Deixando para traz a teoria progressista ou evolucionista dos séculos XVIII e XIX, já encontramos no início do século XX o desencantamento em relação ao progresso como melhoria da condição humana. A "crise do progresso" colocou-se após inúmeras outras crises: Primeira Grande Guerra, depressão, nazismo, fascismo. Ela só se dissiparia a partir do projeto de reconstruçào do pós-guerra (anos 50), e pelo inexorável poder confiado à tecnologia.

Ao longo da história da civilização é possivel perceber que desenvolvimento é um conceito cambiante. Mesmo que a palavra em si (enquanto significante/significativo) tenha ganhado status somente no último século, a idéia que ela encarnava já fazia parte do imaginário do homem que buscava a evolução.

Derivado da idéia de progresso - herança do positivismo - o conceito de desenvolvimento estendeu suas fronteiras para que o homem passasse a articular o mundo de diferentes formas. A sociedade industrial ocidental se impôs, então, como o modelo de crescimento e desenvolvimento. Desenvolvimento ambíguo, cheio de armadilhas e gerador de diferenças sócio-econômicas cruciais que chegam a negar o próprio modelo. Associado ao capitalismo do século $\mathrm{XX}$, ao progresso tecno-científico $\mathrm{e}$ ao aumento de consumo de bens industrializados e serviços, este projeto civilizatório cresceu até encontrar o seu espelho: as bombas de Hiroshima e Nagasaki, graves atentados ao meio ambiente e um contingente populacional crescente de desempregados, subnutridos e desapropriados. Os "excluídos" da sociedade contemporânea.

Do conceitual à realidade criou-se dois mundos: o desenvolvido e o subdesenvolvido. "Sob efeito dos mass media a palavra subdesenvolvimento 
difundiu-se amplamente logo após a Segunda Guerra Mundial, antes de que o conceito tivesse sido objeto de uma tentativa de construçào" (Lacoste, 1983 , p.7). Segundo esta lógica, os países "em desenvolvimento" encontrarse-iam no centro fatalista entre a inferioridade/infância e a superioridade/maturidade.

A partir da década de cinqüenta, o crescimento econômico passou a ser a solução para todos os males e, logo, os países do Terceiro Mundo deveriam atingir a maturidade industrial e, por conseguinte, o desenvolvimento. Mas este modelo de crescimento econômico, com gradações quantificáveis, deixava cada vez mais sequelas sociais e ambientais e, já na década de sessenta, a sociedade civil com seus movimentos sociais começava a revelar a realidade que havia sido encoberta com a idealização oficial do progresso (Serrano \& Luchiari, 1993).

Como muitos autores afirmam (Foucault, 1980/1986; Soja, 1993; Harvey, 1992), a modernidade/modernizaçào sempre esteve associada à metáfora do tempo. A idéia de progresso fortaleceu a submissão da categoria espaço a um objeto de dominaçào e priorizou o tempo histórico e suas qualidades do vir-a-ser. A teoria social, subsidiada pelo historicismo, condicionou a percepçào de mundo à temporalidade do devir do progresso. $\mathrm{O}$ espaço se restringiria ao cenário onde se desenrolava a história do ser social. Foucault foi um autor perspicaz nesta análisc. Para ele,
"A grande obsessão do século XIX foi, como sabemos, a história: com seus temas de desenvolvimento e suspensão, crise e ciclo, temas do passado em etcrna acumulação (...) $A$ era atual talvez seja, acima de tudo, a era do espaço. Estamos na era da simulta- neidade; estamos na era da justaposição, na era do perto e do lon- ge, do lado a lado, do disperso. Estamos num momento, creio eu, em que nossa experiência do mundo é menos a de uma vida lon- ga, que se desenvolve através do tempo, do que a de uma rede que liga pontos e faz intersecções com sua própria trama. Poder- se-ia dizer, talvez, que alguns conflitos ideológicos que animam a polêmica atual opõem os fiéis descendentes do tempo aos decidi- dos habitantes do espaço." (Foucault, 1986, p.22, apud Soja, 1993, p.17) 
Só a partir da década de 70 , a retomada da perspectiva espacial na teoria social (crítica) ganhou maior importância analítica dentro das ciências humanas. Hoje, a representação do espaço, suas escalas justapostas, sua reorganização/recombinação constantes têm gerado questionamentos instigantes para a teoria e para a prática da experiência social.

Esta nova perspectiva, apoiada em um equilibrio interpretativo entre tempo e espaço na teoria social, ainda nào foi totalmente construída. Muitas vozes ecoam neste sentido, mas a primazia do tempo/histórico arraigada em nossa concepçào de mundo, os equivocos dos discursos pósmodernos e uma realidade ao mesmo tempo global e fragmentada dificultam a capacidade de apreensão e de construção de uma teoria social histórica e, ao mesmo tempo, geográfica.

O historicismo teve o mérito de subsidiar uma teoria social que buscava compreender um mundo em constante mutação (social, tecnológica e política). Hoje, espacializar a história é uma perspectiva de grande valia , principalmente na interpretaçào do embate entre os modernos e os pósmodernos. Mas, antes de aprofundarmos a análise sobre o discurso da pósmodernidade e suas críticas, seria importante ouvir ainda algumas vozes que anteciparam a importância da análise espacial para a compreensão da sociedade contemporânea.

\section{ESPAÇO E REPRESENTAÇÃO: MAPEANDO VOZES ISOLADAS}

Voltando a Foucault (1986, p.83), encontramos um conceito importante para a representação da espacialidade da vida social: suas heterotopias, espaços heterogêneos de relações e localizações. Nestes espaços/lugares ele viu mais que a materialidade de um cenário imóvel, morto, não-dialético. Ele mostrou a espacialidade criada e vivida, concreta $\mathrm{e}$ abstratamente pelas práticas sociais, cuja concepção da análise social conjuga as dimensões "horizontal" e "vertical", tempo e espaço, sincrônica e diacrôni- 
ca. O controle social através das "estruturas disciplinares" e a importância do espaço no exercício do poder foram contribuições que influenciaram muitos autores. Para Foucault (1980, p.149), a "história dos espaços" nos daria a ferramenta interpretativa necessária para compreender as estratégias de poder, tanto nas estruturas cristalizadas do habitat como na organização geopolítica.

As narrativas contemporâneas nào devem pregar o fim do historicismo, mas uma história espacializada. É com este objetivo que emergiram as vozes de David Harvey, Edward Soja, Yves Lacoste, Henri Lefebvre e outros. A extensào dos acontecimentos e sua simultaneidade sào tão importantes hoje quanto a seqüencialidade do processo histórico foi para o início da modernidade. Como argumentou Harvey (1992), o próprio desenvolvimento histórico do capitalismo nos propòe isto. A espacialidade instrumental do capitalismo indica que a narrativa histórica deve ser trabalhada em diferentes escalas.

Para Soja (1993, p.35), o espaço, o tempo e o ser social são as dimensões existenciais abstratas que ganham vida como um constructo social e moldam a realidade empírica, sendo simultaneamente moldadas por ela. Se até meados do século XIX a modernização possuía um caráter predominantemente cumulativo, a partir daquele momento ela passou a apresentar transformaçòes sincrônicas, afetando a cultura da modernidade em todas as sociedades predominantemente capitalistas.

Ele considera que também a teoria social, na virada do século, respondeu à modernização com duas posições diferenciadas: a tradição marxista/leninista e a naturalista/positivista. Mas até o desdobramento do "marxismo ocidental" e das críticas à divisão disciplinar, à fragmentação $e$ ao cientificismo, o historicismo possuía a primazia da análise social. Apesar disto, a instrumentalidade do espaço para a reorganização capitalista e seus efeitos disciplinadores já cram percebidos pela teoria estética, vivenciados pclos movimentos de vanguarda e absorvidos pela arquitetura do início 
deste século. Por que entào, a teoria social negligenciou a espacializaçào dos processos históricos? Esta pergunta parece ter várias respostas.

Uma delas é a negação teórica explícita ao determinismo ambiental, desenvolvido pelos discipulos de Friedrich Ratzel a partir de suas concepções sobre "antropogeografia" e "geopolítica" - esta, associada à Alemanha nazista. Outra, foi a recorrente dicotomia entre sociedade e natureza, cujo papel das explicações fisicas era externo aos processos sociais e à consciência humana.

O determinismo geográfico de Ratzel e sua teoria de espaço vital (1882), baseavam-se nas influências do positivismo evolucionista. Ratzel viveu em um período no qual a França e Inglaterra já estavam unidas, enquanto a Alemanha amargava um processo de unificação tardia². O momento seguinte seria a fase imperialista do capitalismo alemão. Ratzel projetou a Geopolítica conceituando o Estado como um organismo (em parte humano e em parte terrestre), na sua relaçào necessária com o solo: "Semelhante à luta pela vida, cuja finalidade básica é obter espaço, as lutas dos povos são quase sempre lutas pelo mesmo objeto. Na história moderna, a recompensa da vitória sempre foi - ou tem pretendido ser - um proveito territorial" (Moraes \& Fernandes, 1990). O "espaço", como instrumento de poder, passou a afigurar-se como um paradigma na Geografia.

Embora Ratzel não negasse as "possibilidades" 3 e criticasse o determinismo imediatista, sua análise foi incorporada pelo Estado visando a

2O Império alemão se constitui em 1871 através do autoritarismo e do expansionismo, tendo a sua frente o primeiro-ministro Bismarck.

'É importante salientar que foi como oposição à "escola determinista" de Ratzel que surgiu, na França, a "escola possibilista", liderada por Paul Vidal de La Blache (18451918) e fundamentada no positivismo funcionalista. Este colocou a questão da pluralidade das linhas de evolução através da relação de um conjunto de fatores (étnicos, técnicos, econômicos, ambientais, históricos entre outros) que iriam explicar as diferenças entre as áreas geográficas do globo. "Vidal de La Blace definiu o objeto da Geografia como a relação homem-natureza, na perspectiva da paisagem. Colocou o homem como um ser ativo, que sofre a influência do meio, porém que atua sobre este, transformando- 
instrumentalizaçào da unificaçào da Alemanha. A análise de Ratzel e sua apropriação pelo nazismo foram criticadas pelos franceses, por colocar o homem numa relaçào de dependência entre o território e o Estado, garantindo a este o domínio ideológico.

Quanto à dicotomia entre sociedade e natureza podemos dizer que esta era, ao mesmo tempo, uma nova concepçào de mundo e um projeto científico visando a autonomização e especialização da ciência. Assim, enquanto as concepçòes do Iluminismo pregavam o fim dos mitos, a "erradicação do animismo", do sobrenatural para transformar o homem em sujeito pleno de razão e de poder (Horkheimer \& Adorno, 1969); a ciência separava sociedade e natureza objetivando uma racionalidade instrumental que lhe fornecesse maior poder analítico em sua ótica positiva.

Neste sentido a Geografia Francesa, liderada por Paul Vidal de la Blache, constrói uma análise menos dicotomizada entre homem e natureza. Contrapondo-se à Geografia Alemã, a Geografia Francesa deixou de lado a abordagem sobre o Estado e buscou estudar o "solo" e a "paisagem" para caracterizar o domínio do homem sobre o seu território. O discurso de entào era de que a ciência nào poderia estar a serviço do Estado, pois ela é neutra e deveria apenas descrever para melhor entender. Logo em seguida, a contradiçào se colocaria com o estudo das regiōes ou, a Geografia Colonial. A própria história do pensamento geográfico e, principalmente, o longo período em que ela se colocou como uma ciência "descritiva" dos fenômenos deu a Geografia um caráter utilitário.

O que se buscou com o "possibilismo" foram os aspectos básicos da investigaçào empírica - fase em que o funcionalismo se organiza apoiando-se na abordagem ideográfica - através dos estudos locais e das análises particularizadas de cada área, região e grupos humanos .

\footnotetext{
o.(...) Assim, na perspectiva Vidalina, a natureza passou a ser vista como possibilidades para a ação humana"(Moraes, 1981:68).
}

Temáticas, Campinas, 4(7):191-238 jan./jun. 1996 
O nascimento da Geografia Francesa estava diretamente relacionado aos acontecimentos políticos e econômicos da segunda metade do século XIX. A Alemanha e a França eram duas potências nacionais em confronto pelo poder e pelo expansionismo no continente europeu. A guerra francoprussiana, em 1870, consuma a vitória da Prússia (atual Alemanha) com a anexação da Alsácia e Lorena, região francesa rica em carvão, fcrro e recursos hídricos. Como o expansionismo alemão legitimava-se com as concepções geopolíticas de Ratzel, era crucial a França também desenvolver um projeto cujas concepções se adequassem ao liberalismo burguês da Revolução Francesa e combatessem, ao mesmo tempo, a ideologia imperialista alemã.

O "possibilismo geográfico" nasce, então, deste projeto. A geografia é instrumentalizada pelo Estado para pensar o espaço geográfico objetivando o reconhecimento de novos territórios. La Blache abandonou a Geografia Política, defendeu a tese da "neutralidade científica" e criticou em Ratzel seu caráter naturalista e sua concepção fatalista e mecanicista da relação homem-natureza. Em torno destas formulações, a Geografia Francesa substituiu o paradigma naturalista pelo funcionalista e a abordagem nomotética pela ideográfica.

La Blache priorizava o estudo de populações rurais (coletores, agricultores e criadores) que apresentassem, como traço fundamental, a autonomia. Segundo ele, estas populações dominavam a natureza a partir de um conjunto de elementos materiais e espirituais: técnicas, tradição (usos e costumes) e processos criativos (arte). Este conjunto de elementos, possuidores de uma origem social, permitia às populações utilizarem as possibilidades do meio físico e construírem, historicamente, uma relação de equilíbrio entre natureza e sociedade. Às atividades dos grupos humanos, envolvendo todas estas relações, La Blache conceituou de gêneros de vida:

"O conceito de gênero de vida proposto por Vidal de La Blache (...) é também um desses numerosos paradigmas que orientam a geografia humana moderna. Segundo esse enfoque, seria por in- 
termédio de uma série de técnicas confundidas com uma cultura local que o homem entra em relação com a natureza. $O$ espaço como objeto de estudo seria o resultado de uma interação entre uma sociedade localizada e um dado meio natural: um argumento sob medida para reforçar a idéia de região como unidade de estudo geográfico" (Santos, 1980, p.19)

A diferenciação cultural somada a diferenciação do meio físico explicaria, para La Blache, a multiplicidade dos gêneros de vida. Esta teoria, associada à concepçào de "progresso" que La Blache desenvolveu como sendo o "fruto de relaçòes entre sociedades com gêneros de vida diferentes, num processo enriquecedor" (Moraes, 1981, p.71), legitimava a ação colonialista francesa na Ásia e na África e o Estado francês como o agente civilizador.

La Blache desenvolveu o método empírico-indutivo, fazendo da observação e da descrição as técnicas de um mapeamento detalhado de sociedades até então desconhecidas. Desenvolveu também o conceito de $\underline{\text { Região, }}$ instrumento analítico que, nas mãos de La Blache, passou a ser o próprio objeto de pesquisa - dotado de individualidade física e sóciocultural. A partir dai a "regiào" c nào mais o "organismo terrestre" ou o "espaço vital", tornou-se o conceito-chave da Geografia.

Se, por um lado, a Geografia Regional desenvolvida pelos discípulos de La Blache, através de suas monografias, recebeu muitas críticas principalmente pela falta de procura de leis gerais; por outro lado, ela produziu uma exaustiva compilaçào de dados regionais que auxiliaram na criaçào de diversas especializaçòes para a Geografia Física e Humana.

Mas a própria questão dos "limites da regiào" da Geografia Tradicional são muito controversos: a concepção de regiòes homogêneas (regiòes naturais, históricas, étnicas, econômicas) sempre buscou uma uniformidade contraditória à realidade. Segundo Yves Lacoste (1988) estes conjuntos espaciais (climáticos, topográficos, étnicos, administrativos) seriam apenas categorias parciais da realidade. A paisagem, conceito caro à geografia de $\mathrm{La}$ Blache, seria a "regiào natural" em seu "conjunto homogêneo", somado 
(como interposição, não interrelação) a fatores econômicos, estruturas sociais, demográficas... todas variáveis girando em torno de um certo equilíbrio.

À parte as criticas, a Geografia Tradicional Francesa reflete um longo período de sistematizaçào desta ciência através dos estudos da Geografia Regional. Esta última, mesmo superada, serviu como referência para os desdobramentos posteriores da Geografia, fôsse para combatê-la, fôsse para revisitá-la. ${ }^{4}$

Embora Vidal de la Blache se ausentasse de uma abordagem política da relação entre os homens, ele concordava que "as causas geográficas não agem sobre os homens senão por intermédio dos fatos sociais". Esta afirmação antecipa uma visão menos dicotomizada da análise dos grupos sociais com o ambiente que os circundam.

Para a Sociologia parecia ser dificil fazer esta correlação sem temer o determinismo ambiental. Claro que o espaço como categoria analítica era objeto privilegiado da Geografia, mas mesmo Émile Durkheim, que tinha conhecimento das obras de Ratzel e La Blache e que em sua obra cria as bases para a elaboração do conceito de "espaço social", coloca numa posição secundária a influência do ambiente fisico na diferenciação social. Ele reconhece a importância da morfologia social, mas considerando-a como a "forma exterior e material da sociedade":

"Este território, suas dimensões, sua configuração, a composição da população que se desloca sobre a superficie, são fatores naturalmente importantes da vida social; este é o substrato (...)"'5 (Rodrigues, 1990, p.42)

tOs principais representantes da Geografia Regional, sob influência de La Blache são: E.Demartonne, J.Brunhes, A.Demangeon, C.Vallaux, H.Baulig, R.Blanchard, J.Max. Sorre entre outros.

5Em uma nota de rodapé Durkheim chega a aludir que "o que os alemães chamam de Antropogeografia não deixa de se relacionar com o que chamamos de Morfologia Social", e cita trabalhos de Ratzel, na Alemanha, e de Paul Vidal de La Blache, na França (Rodrigues, 1990, 42) "Divisões da Sociologia: As Ciências Sociais Particulares", reproduzido de La Science Sociale et L'Action. 
Apesar de Durkheim afirmar que os fatos sociais de ordem anatômica diferem dos modos de agir, pensar e sentir apenas pelo grau de consolidação que atingiram, sendo que ambos possuem relações estreitas e inseparáveis, o que os coloca dentro da área de estudo sociológico, é à fisiologia social que Durkheim associa a vida e a complexidade sociais. Claro que é preciso reconhecer que Durkheim estava preocupado com o projeto de autonomizaçào da sociologia enquanto ciência, o que o levou a uma delimitaçào rigorosa em relaçào no método, aos conceitos e ao próprio campo de investigaçào sociológica. $\grave{A}$ sociologia caberia a interpretaçào dos fatos sociais que revelassem modos de agir coletivos, às outras ciências caberia a investigaçào mais refinada dos modos de ser que também se impõem aos indivíduos mas, estão relacionados a ordem anatômica ou morfológica.

Apesar desta justificativa metodológica, Durkheim - pelo menos em suas obras iniciais - demonstra dúvidas quanto a importância das representaçòes sociais contidas no espaço.

"A sociologia não se pode desinteressar daquilo que concerne ao
substrato da vida coletiva. No entanto, o número e a natureza das
partes elementares de que é composta a sociedade, a maneira pela
qual estão dispostas, o grau de coalescência a que chegaram, a
distribuição da população na superfície do território, o número e
a natureza das vias de comunicação, a forma das habitações, etc.,
não parecem, a um primeiro exame, passiveis de se reduzirem a
modos de agir, de sentir e de pensar" (1990, p.9, grifos nossos).

A vida cristalizada nas formas materiais construídas e organizadas pela sociedade estão, para Durkheim, subordinadas às divisões morais da vida social - mesmo que estas se apoiem de alguma forma na natureza fisica. Ele reconhece um parentesco entre "vida" e "estrutura", assim como a natureza comum dos fatos sociais de origem morfológica e fisiológica, mas ao correlacionar órgão e funçào só focaliza o primeiro na medida em que a segunda o demande como um recurso explicativo do processo de vir a ser. 
Sua preocupaçào com o ambiente social, então, era definida em termos de diferenciação social, onde o ambiente físico ganhava uma importância secundária. A prioridade dada ao social deixava apenas subentendido que forma e função faziam parte de uma mesma estrutura ${ }^{6}$.

Ao analisar a solidariedade mecânica ${ }^{7}$ Durkheim ressalta "que todos os povos que ultrapassaram a fase do clã constituem distritos territoriais (posto, comuna, etc.) (...)". Mas, segundo sua análise, os laços sociais determinados pela territorialidade se mostraram artificiais em relação a consangüinidade na qual se baseava a vida social anterior, e logo foram ultrapassados pelos laços profissionais.

Apesar dele concordar com a importância dos laços territoriais ${ }^{8}$, salienta que, desde a Idade Média "a organização segmentar perdeu sua relevância", apontando para uma crescente homogeneização com o desenvolvimento das sociedades. A territorialidade foi para ele um isolamento tênue e facilmente transposto:

"Ora, as diversidades locais não podem se manter do mesmo modo que subsiste a diversidade dos meios. As divisões territoriais são pois cada vez menos baseadas na natureza das coisas e, por conseguinte, perdem seu significado. Quase se pode dizer que um povo é mais avançado na medida em que elas tenham um caráter mais superficial" (in Rodrigues, 1990, p.94).

'Renato Ortiz, em sua introdução para a versão brasileira de As Formas Elementares da Vida Religiosa (1989), observa que na primeira fase da obra de Durkheim este atribuía uma prioridade maior à morfologia social. O que Ortiz enfatiza, neste caso, é uma questão de cunho metodológico das obras iniciais em relação à uma segunda fase, na qual Durkheim daria maior ênfase às questões de representação coletiva. Ortiz não está se remetendo ao determinismo geográfico, questão que estamos centralizando nesta análise.

'DURKHEIM, Émile (1893-1a ed.) A Divisão do Trabalho Social (Livro I), in Rodrigues (1990).

s"A distribuição geográfica coincide, sem dúvida, geralmente e a grosso modo com uma certa distribuição moral da população. Cada provincia, por exemplo, cada divisão territorial tem certos usos e costumes especiais, uma vida que the é própria. Ela exerce assim sobre os indivíduos que são impregnados pelo seu espirito uma atração que tende a mantê-los no lugar e, ao contrário, a expulsar os outros", in "Preponderância Progressiva da Solidariedade Orgânica", Livro 1, Cap.4/7, in Rodrigues (1990).

Temáticas, Campinas, 4(7):191-238, jan./jun. 1996 
Durkheim condicionou o desenvolvimento da solidariedade orgânica ao enfraquecimento da solidariedade mecânica, assim como os laços profissionais de uma sociedade que tendia a homogeneização ao enfraquecimento dos laços territoriais. Pois bem, Durkheim acreditava que a preponderância crescente da solidariedade orgânica, baseada na divisão do trabalho, iria integrar a sociedade num todo orgânico. Esta nova solidariedade eliminaria o apego social aos laços territoriais e incrementaria os laços profissionais. Esta era a sua tese; por isto, mesmo fazendo referências à Antropogeografia ele tinha que considerá-la ultrapassada.

Nas Regras do Método Sociológico Durkheim defende a importância da morfologia social nas associaçòes da vida coletiva e na explicação sociológica. Para ele, todos os elementos associados (coisas e pessoas) e a disposição destes no espaço formam o meio interno de uma sociedade. "A origem primeira de todo processo social de alguma importância deve ser buscada na constituiçào do meio social interno"'(1990, p.98). Mas, ele adverte, as coisas (objetos materiais e costumes, direito, monumentos etc.) influenciam na velocidade e na direçào da evoluçào social, embora nào possuam poder motor para gerar seu movimento, nào sào dotadas de força viva que lhes assegure essa capacidade propulsora. Sào os homens em sua vida comum, coletivizando bens simbólicos e materiais e produzindo uma intensidade dinâmica, que possuem a capacidade de fator (ativo) determinante da evoluçào da vida coletiva.

Numa outra leitura de Durkheim podemos pensar no fato social como "toda maneira de agir, fixa ou não, susceptivel de exercer sobre o indivíduo uma coação externa" (1990, p.11). Este modo de ação, ao cristalizar-se em modos de ser, permanece como fato social. Segundo esta perspectiva, o espaço no qual a sociedade se envolve é coisa, é exterior ao indivíduo, exerce influência coercitiva sobre a sociedade e seus indivíduos, e é construído pelas ações e representacões sociais. Ou seja, é fato social e não apenas reflexo da estrutura social. 
Ainda que Durkheim custasse a admitir o espaço enquanto estrutura social de representação dinâmica, considerando-o apenas como o fixo, o próprio Durkheim nos permite fazer esta leitura. O problema é que em sua preocupaçào em delimitar o campo sociológico e defender-se do determinismo ambiental," o determinismo social tornou-se seu principal argumento.

Para a sociologia este procedimento era uma virtude, para a geografia - infelizmente - faltou a perspicácia em ler, na época, a teoria de Durkheim com o olhar do geógrafo, transpondo para o espaço (social) as noções de coerção social e representação coletiva. Talvez este procedimento tivesse evitado a querela inócua entre "determinismo" e "possibilismo", que serviu para acobertar a questão principal: as representaçòes de poder contidas nas lógicas espaciais estruturadas pelos Estados.

Em As Formas Elementares da Vida Religiosa (1912), sua última grande obra, é possivel resgatar uma leitura mais refinada sobre duas concepções: natureza c espaço. Nesta, ele explora a unicidade existente entre o "reino social" e o reino natural, objetando que a sociedade não difere da natureza já que ela representa a sua manifestaçào mais elevada. Os símbolos e as representações produzidos pela sociedade esforçam-se por se aproximarem da natureza, assim como as categorias do entendimento - e aqui estamos pensando na categoria espaço, especificamente, mas ele também cita o tempo, gênero, número, substância, personalidade etc., que além de possuírem uma origem social, são ferramentas analiticas possuidoras de um valor objetivo.

"Todo meio fisico, afirmam efetivamente alguns dos críticos, exerce coerção sobre os seres que sofrem sua ação; pois estes são obrigados, em certa medida, a se adaptarem a ele. Mas entre estes dois tipos de constrangimento está toda a diferença que separa o meio fisico do meio moral. A pressão exercida por um ou vários corpos sobre outros corpos, ou mesmo sobre as vontades, não pode ser confundida com a que exerce a consciência de um grupo sobre a consciência de seus membros. A coerção social é devida não a certos arranjos moleculares, e sim ao prestígio de que estão investidas certas representações: nisto está o que apresentam de inteiramente especial" (1990:XXXXXXI). 
"Elas aparecem então não mais como noçōes muito simples, que o primciro observador pode deduzir de suas impressões pessoais e que a imaginação popular teria desencontradamente complicado, mas, ao contrário, como sábios instrumentos de pensamento, que os grupos humanos forjaram laboriosamente ao longo dos séculos e onde acumularam o melhor de seu capital intelectual". (in Rodrigues, 1990, p.160)

Assim ele afirma que "o que está na base da categoria de tempo é o ritmo da vida social", e que a categoria espaço, com sua origem social, se estende através de múltiplas representações coletivas (in Rodrigues, 1990, p.158-159). Durkheim inovou no estudo da diferenciação social e abriu várias possibilidades de investigaçào do espaço produzido como representaçào" e coerçào sociais. Se ele não avançou nesta direção é provavelmente porque não cra este o seu projeto, e também porque as condições históricas da ciência e particularmente da sociologia, conduziram-no a outro rumo.

A noçào de "espaço social", originada da influência de seus estudos, foi desenvolvida na década de cinqüenta por dois estudiosos franceses: o geógrafo Maximilien Sorre, e o sociólogo Paul-Henri Chombart. Sorre lançou as bases para uma definição do conceito e Chombart o aplicou e o desenvolveu olhando mais atentamente para problemas urbanos ${ }^{11}$.

Sorre parte de uma leitura de Durkheim:

"O conhecimento do espaço social supõe o conhecimento prévio do espaço geográfico. As áreas sociais não se sobrepõem às áreas geográficas: podem ultrapassá-las; inversamente, uma área geográfica abrange diversos espaços sociais. O espaço geográfico, entretanto, definido em seu sentido mais amplo, corresponde

10Ver principalmente seu artigo, em parceria com Marcel Mauss "Algumas Formas Primitivas de Classificação". (Contribuição ao estudo das representações coletivas) in Rodrigues (1990).

"SORRE, M. "Les Fondements de la Géographic Humaine", 3 V., Paris, 1943/1952 e, LAUWE, P.H. Chombart de et alii "Paris et L'Agglomeration Parisienne", Paris, 2 V., 1952. Para uma exposição mais detalhada da influência destas obras na construção do conceito de "espaço social" ver: Buttimer (1986). 
àquilo que Durkheim denominou substrato dos fatos sociais". (in Megalc \& Fernandes, 1984, p.153)

Mas ele considerava que para o sociólogo seria dificil abarcar o conceito de espaço geográfico. Acrescenta, então, o ambiente fisico ao social, ampliando a noção de substrato/ambiente social e construindo um novo conceito para o qual as explicações físicas interagem com as explicações sociais. O espaço social assim construído possibilita uma visão menos dicotômica entre natureza e sociedade e entre "uma ordem subjetiva interna (valores, preferências, atitudes, tradições e aspirações) e uma ordem espacial externa". Discípulo de La Blace, ele preocupava-se com a "ccologia humana" enquanto um processo de interação entre as sociedades e seu ambiente físico.

Sorre desenvolveu o conceito de espaço social a partir da diferenciaçào de áreas, cuja identidade de cada uma se relacionava as percepções espaciais de seus habitantes e a complementariedade entre a natureza e a sociedade num processo de construçào da paisagem. Ele utilizava-se de categorias macroscópicas e microscópicas (linguagem/grupos étnicos, Estados nacionais e estilos de vida) e era, assim como Vidal de La Blache, um estudioso do meio rural.

Chombart utilizou-se do mesmo conceito para trabalhar o ambiente urbano em sua "hierarquia de espaços" onde os grupos sociais interagem. Deu preferência aos grupos profissionais, sociais e outros, mas sempre numa escala restrita ao ambiente urbano.

A influência recíproca entre estes cientistas sociais, os embates de idéias, as contribuições críticas demonstram um enriquecimento crescente das Ciências Humanas. Se a coesão entre elas não foi maior, não foi devido à incapacidade de seus mentores ou ao distanciamento real entre os seus objetos de análise, mas ao projeto de ciência positiva que pressupunha a autonomização e a fragmentação do conhecimento científico.

Sobre a participação da ciência histórica neste contexto é importante ressaltar pelo menos uma passagem. 
A História e a Geografia nasceram juntas - uma para explicar a diversidade de fenômenos que ocorrem no tempo, e a outra no espaç. ${ }^{12} \mathrm{E}$ irônico, mas no debate colocado entre tempo e espaço, sociedade e natureza, na virada do século, a História aproximou-se mais da Geografia que a Sociologia. Apesar das primeiras serem, por definição, ciências que competiam num campo muito próximo, havia entre elas uma interaçào tanto pela semelhança quanto pela diferença.

Paul Vidal de la Blache foi professor de Lucien Febvre, colaborou com sociólogos e historiadores e fundou a revista Annales de Géographie (1891). Entre os colaboradores das três revistas, Annales de Géograpbie, Annales d'Histoire Économique et Sociale (1929-39) ${ }^{13}$, fundada por Lucien Febvre e Marc Bloch e L'Anné Sociologique, arquitetada por Émile Durkheim (1896), havia um "tráfico de influências" que alimentava uma tensão criativa.

A tensão intelectual da época opunha o determinismo geográfico à liberdade humana. Enquanto Durkheim mantinha o devido distanciamento, Febvre apoiou La Blache e contestou Ratzel. Estes "novos historiadores" (Febvre e Bloch) interessavam-se pela geografia histórica, pela análise interdisciplinar e pela história-problema, chegando a debater a noção de regiào "argumentando que (na investigação) esta dependia do problema que se tinha em mente" (Burke, 1991, p.26).

Mas foi com a obra "O Mediterrâneo e Felipe II" de Braudel (1949) que a geografia histórica ficou consagrada. Braudel dedica a primeira parte do livro (trezentas páginas) à história do homem em relação ao seu meio físico. Esta atitude ressalta a importância do espaço na história e assume as

${ }^{12} \mathrm{Kant}$, um dos fundadores dos principios teóricos da Geografia Alemã, já havia afirmado que a experiência humana dividia-se em duas espécies: narrativa e descritiva; a primeira era a história, a segunda, a geografia.

${ }^{13}$ A revista teve três títulos além deste: Annales d'Histoire Sociale (1939-42/45); Mélanges d'Histoire Sociale (1942-4); Annales: Économies, Sociétés, Civilisations (1946-); mas ficou conhecida como "Escola dos Annales". Para uma descrição sistemática sobre sua origem, influências e desenvolvimento ver BURKE, P. (1991)

Temáticas, Campinas, 4(7):191-238 jan./jun. 1996 
influências marcantes dos geógrafos Vidal de la Blache, Maximilien Sorre e, inclusive, Ratzel.

Superando seu mestre Febvre, Braudel uniu a geografia à história de uma forma menos utilitária. Enquanto o primeiro dispunha do espaço como cenário, o segundo fez do tempo geográfico uma nova forma de interpretar a história, integrando várias estruturas. Superando também Durkheim, ele acaba demonstrando que mesmo as estruturas mais fixas, mais lentas no processo de transformaçào podem responder sobre o comportamento humano. Elas nào só podem constranger, determinar ou disciplinar mas podem também ser instrumentos de criatividade humana.

Mas até o início do século a natureza e o espaço produzido socialmente eram, predominantemente, tidos como uma contingência das sociedades. Só aos atores sociais era dada a capacidade de fazer a história. O desprezo pelo determinismo ambiental impediu, durante muito tempo, que a produção do espaço fosse considerada como um processo social ${ }^{14}$.

Ao espaço eram dadas as qualidades de passividade e medida; ao tempo histórico as de ação e sentido. Soja (1993), considera que, de um modo geral, tanto os desdobramentos da teoria marxista quanto os reducionismos positivistas calaram, até o final da década de sessenta, sobre a importância da produção espacial na análise dos processos sociais.

Do ponto de vista da Geografia a partir da década de cinqüenta, a análise regional deixa de lado a procura de espaços uniformes e passa a preocupar-se com as redes de fluxos (de capitais, de população, de decisões etc.), considerando-os importantes organizadores de uma região.

O paradigma desenvolvimentista do pós-guerra e a Revolução Quantitativista da Geografia, incrementaram a instrumentalização do trabalho científico, direcionaram os novos objetivos dos pesquisadores e acabaram por alterar a visão sobre os antigos objetos de análise. Para Kuhn

14Para Soja (1993), apenas o marxismo francês, que nunca negou totalmente a teorização espacial, é exceção neste caso.

Temáticas, Campinas, 4(7):191-238, jan./jun. 1996 
(1994), esta questão não se coloca como o resultado de um processo cumulativo do conhecimento mas como um momento de ruptura onde um novo problema se apresenta gerando novos esquemas de interpretação da realidade. Seguindo o pensamento de Kuhn, naquele momento, investigações extraordinárias subverteram a tradição e salientaram as suas anomalias. Mais ainda, a busca constante de respostas para o paradigma regional acabou por conduzir a Geografia Tradicional - enquanto "ciência normal"- a uma reformulaçào paradigmática. Claro que, as condiçòes externas ao desenvolvimento da ciência geográfica (históricas, tecnológicas, sociais, econômicas, entre outras) ajudaram a transformar as anomalias em fonte de crise aguda.

Para a Geografia este foi um momento de notável desenvolvimento relacionado ao uso de novas técnicas, de novos métodos de aproximação da realidade e aos progressos da automação. Estava aberto o caminho para a "Nova Geografia" que se colocou em oposição radical à Geografia Tradicional.

O conceito de "rede de fluxos" abriu caminho para análises do espaco funcional, da rede de centros e o conceito de nodalidade de Mackinder - que já havia sido utilizado por La Blache no sentido de concentrador/expulsor de fluxos de maior complexidade. Assim, os "gêneros de vida", mais associados ao meio rural, dào lugar as análises dos grandes centros urbanos. O espaco funcional foi definido pelas redes em sua trama de relações, não por seus limites. O Planejamento Regional a partir do enfoque sobre sistemas, foi um refinamento do espaço funcional (que desenvolveu os conceitos de regiào nodal, modelo centro-periferia, difusào de inovaçòes, hinterland) que se aproximava muito dos modelos econômicos.

Assim, a perspectiva histórica ou evolutiva dos fatos geográficos foi substituída pela visão sistêmica dos "arranjos espaciais" na "Revolução Quantitativa"15 do pós-guerra. Mas a valorizaçào exagerada da análise sin-

${ }^{15}$ Esta Nova Geografia foi qualificada por dois adjetivos: quantitativa expressando a aplicação intensiva de técnicas estatísticas e matemáticas e teorética, visando um apro- 
crônica, da "técnica pela técnica" e da especialização desprezou a análise dos processos e do espaço como locus de contradições, transformação e reprodução das relações sociais.

Sobre a Geografia Quantitativa sempre pairaram dúvidas fundamentais se ela se constituiu num paradigma ou num método. Seja qual for a resposta, a Geografia Quantitativa pecou cientificamente ao privilegiar os métodos e as técnicas em relaçào à realidade. Também o Planejamento Regional à serviço dos projetos desenvolvimentistas reproduziu, na época, o modelo centro-periferia, comprometendo mais uma vez a Geografia em termos ideológicos e utilitários.

A crítica que se instaurou contra a Geografia Quantitativa era proveniente da Geografia Nova/Marxista/Crítica. Esta vertente contestou a falsa neutralidade da ciência geográfica e aprofundou os estudos sobre o "espaço social"- produzido pelos homens, enquanto um instrumento de poder do Estado e da sociedade. O espaco social, produto e ao mesmo tempo condicionante das diversas estruturas (sociais, econômicas, políticas, cognitivas), passa a ser a principal categoria analítica da Geografia Marxista das décadas de setenta e oitenta. Este conceito passou a ser fundamental na análise da representação das diferenças sócio-econômicas produzidas pelo capitalismo.

Como Harvey (1992) e Soja (1993) reconhecem, foi Henri Lefebvre quem recupcrou a categoria espaço como fonte de poder social. Este despertar da perspectiva espacial, revigorado pela abordagem dialética, foi mais que aceitar a importância da descriçào, localização e limitação espacial para a açào social. Foi uma interpretaçào renovadora para a teoria social crítica. Harvey, inicialmente, criticou Lefebvre pela insistência deste em colocar o espaço como possuidor de um papel decisivo na estrutura da moderna sociedade capitalista; mas, já na década de oitenta criticou diretamente a dificul-

fundamento teórico e metodológico. $\mathrm{O}$ desenvolvimento destas perspectivas levaram Ian Burton (1963) a classificar este periodo como o de uma "revolução". 
dade das ciências sociais, ligadas ao marxismo ocidental e ao historicismo, em accitar a importância da análise espacial para a teoria social.

"Marx, Marshale, Weber e Durkheim têm isto em comum: todos priorizam o tempo $\mathrm{c}$ a história em relação ao espaço e à geografia e, quando chegam sequer a abordar estes últimos, tendem a encará-los, não problematicamente, como o contexto ou a localização estável da ação social" (Harvey, 1985, p.141, apud Soja, 1993).

Em seu livro mais recente, Harvey (1992) aceita as colocações de Lefebvre $^{16}$ e chega a propor um materialismo histórico geográfico. Ele adota a perspectiva materialista na análise das concepções de tempo e espaço - suas categorias analíticas fundamentais, subordinando-as aos processos materiais que servem à reproduçào da vida social.

Primeiramente ${ }^{17}$ ele explora as experiências do tempo e do espaço no cotidiano da vida individual e social, mas logo conclui que estas categorias devem ser interpretadas à luz da açào social que, de um lado, é disciplinada pela "malha repressiva de controle social", mas de outro, gera movimentos criativos e clandestinos que também sào espacializados.

Harvey descreve o jogo social onde o poder está diretamente relacionado ao domínio do espaço, ao controle do tempo e a posse de dinheiro, salientando como a inter-relação e a oscilaçào entre estas três categorias vem moldando a história do capitalismo. Ele caracteriza, a partir de meados do século XIX até meados do século XX, a aceleração do processo de "compressão tempo-espaço" reduzindo a uma mesma lógica o fragmentado e o global. Ele explora a evoluçào do espaço representado pelo mapa e do tempo pelo calendário e cronômetro, mostrando como o amadurecimento do pensamento iluminista confinou "o livre fluxo da prática e da experiência humanas a configuraçòes racionalizadas" (ibid., p.230). Para ele, este esforço

\footnotetext{
${ }^{16}$ Embora ainda discuta com cle as relações dialéticas entre o espaço vivido, o percebido e o imaginado.

17Ver especialmente a Parte III "A experiência do espaço e do tempo" in HARVEY, D. (1992) Condição Pós-Moderna.
}

Temáticas, Campinas, 4(7):191-238 jan./jun. 1996 
foi confirmado pela propriedade privada, de um lado, e pela popularização do relógio, de outro, conjugando a visão totalizante a um mundo fragmentado.

Harvey faz um paralelo entre a estética da arte, o pensamento social e cultural e os acontecimentos politico-econômicos. Todos, nas raízes do modernismo, já possuíam como elo comum uma postura esquizofrênica entre a unidade e a diferença, a globalizaçào e a fragmentação, o espaço e o tempo, as forças homogeneizantes do dinheiro $\mathrm{e}$ da troca de mercadorias e a emancipação humana. Num primeiro momento, é nesta dualidade que para Harvey subsiste a lógica da modernidade. É inclusive na exploração da dialética entre lugar e espaço que Harvey encontra a estetização da política local, regional ou nacional, espacializando uma açào política que se superpõe as lealdades à classe, trazendo à cena geopolítica um Estado legitimado mais pelos valores estéticos que pelos sociais. Harvey se utiliza das palavras de Nietzsche para dizer que a busca de uma nova moralidade na ciência geopolítica (então em alta com Ratzel, Camille Vallaux, Mackinder e Mahan) tinha em sua essência a "vontade de poder".

Para o modernismo "heróico", após 1920, Harvey ainda vê uma arena de combate entre a sensibilidade universalista e a localista. Mas em seguida, apesar do construtivismo e dos movimentos de vanguarda, é a estética dos espaços organizados e submetidos a ordem totalizante do controle racional que ganha a batalha.

Neil Smith (1984), um discípulo de Harvey, também se afasta do marxismo ortodoxo e nos mostra como o desenvolvimento da paisagem material apresenta-se como um processo de produção da natureza. Ele argumenta que, no processo de acumulação de capital a natureza é cada vez mais produto da produção social e, ao nível mais abstrato, é na produção da natureza que o valor de uso $\mathrm{c} o$ valor de troca fundem espaço e sociedade.

Voltando a Lefebvre e a outro momento histórico, encontramos a crítica ao reducionismo dogmático na interpretação de Marx, a influência do estruturalismo de Althusser e da fenomenologia existencial, e também dos 
movimentos culturais franceses (cubismo, surrealismo). Lefebvre incorporou definitivamente a espacialidade na teoria social e recontextualizou - o materialismo dialético. Se no início dos anos setenta tanto Harvey quanto Castells criticaram-no é porque temiam a formaçào de uma abordagem autônoma e separatista do urbanismo, isolando-o numa estrutura teórica à parte. Eles temiam também a reificação ou fetichização da análise espacial.

Castells, em A Questão Urbana (1977, p.115), também associou a teoria espacial à teoria social geral. Ele contribuiu para a construçào de uma dialética sócio-espacial ao denominar o espaço como produto material da interaçào entre cultura e natureza. Criticou a visào espacial como simples reflexo da sociedade, mas deu ênfase à estrutura social; no que Lefebvre foi mais além ao associar a formaçào de classes às relações tanto sociais quanto espaciais de produção. Neste sentido, Lefebvre focalizou a problemática social da divisào do trabalho numa perspectiva sócio-espacial, unindo as duas estruturas.

Também algumas vozes vindas da sociologia urbana, que já havia sido representada pela Escola de Ecologia Urbana de Chicago ${ }^{18}$, com seu viés ambientalista, levantaram-se no final da década de setenta, para combater a demasiada importância teórica dada a análise espacial ${ }^{19}$.

Mas Lefebvre seguiu o seu caminho para tratar das influências de um planejamento espacial instrumentalizado que penetrava cada vez mais nas práticas da vida cotidiana. Ele analisou também os efeitos homogeneizantes do capitalismo moderno no contexto da urbanização/espacialização, sempre em diálogo com Marx. Sua principal obra La Procuction de L'Espace (1974) é a confirmaçào de que o capitalismo cria uma espacialidade própria,

\footnotetext{
${ }^{18}$ Este grupo, liderado principalmente por E.W. Burgess, Robert E. Park, L. Wirth e outros desenvolveu pesquisas cuja tônica cra a associação entre as formas espaciais e a produção de práticas culturais.

"Soja (1993) exemplifica esta posição critica com o trabalho de Peter Sauders, "Social Theory and the Urban Question", 1981.
} 
sustentando-se por uma ideologia social, e se reproduz - ao mesmo tempo - através da homogeneizaçào, fragmentação e hierarquização.

Com estas e outras contribuiçòes, de geógrafos e sociólogos, é possivel afirmar que o debate sobre a interação entre processos sociais e formas espaciais entrou definitivamente para o campo da teoria social, principalmente através dos estudos marxistas contemporâneos. Harvey (1992) e Soja (1993, p.71) avançam nesta discussão ao afirmarem que não só o urbano das décadas de sessenta e setenta possuiam uma espacialidade própria - o que era muito fácil constatar - mas a própria economia capitalista, em sua escala "global", também se rearticulou com um novo processo de espacialização.

Milton Santos, um dos grandes nomes da Geografia contemporânea e possuidor de uma extensa obra norteadora para a Geografia Crítica brasileira, escreveu:

"O espaço não é um pano de fundo impassivel e neutro. Assim, este não é apenas um reflexo da sociedade nem um fato social apenas, mas um condicionante condicionado, tal como as demais estruturas sociais. O espaço é uma estrutura social dotada de um dinamismo próprio e revestida de uma certa autonomia, na medida em que sua evolução se faz segundo leis que the são próprias. Existe uma dialética entre forma e conteúdo, que é responsável pela própria evolução do espaço." (Santos, 1988, p.15)

Apesar da dialética sócio-espacial ter se tornado um caminho interpretativo sólido para a perspectiva do materialismo histórico, muitos problemas epistemológicos ainda eram colocados como entraves para a abordagem marxista. Muitos autores associaram o "fetichismo" espacial a um ecletismo perigoso que não se conciliaria com a análise das classes ou mesmo com o materialismo histórico. Thompson (1981), complementa esta crítica em a $A$ Miséria da Teoria ao reafirmar o primado da história e do historicismo, do diacrônico sobre o sincrônico, contrapondo o marxismo britânico à tradição marxista francesa. Em discussão com Althusser cle desenvolve um ardoroso debate entre estrutura e processo. 
De um modo geral as teorias marxistas se aproximariam mais das análises espaciais a partir da década de sessenta. A crise geral do capitalismo, suas contradições sócio-espaciais e o desenvolvimento desigual reaproximaram esta perspectiva. Contudo, vale lembrar que o marxismo ocidental já havia produzido suas teorias sobre o imperialismo. Na década de setenta, ele concentraria seus esforços na análise da economia política da urbanização.

Após uma longa série de publicaçoos, oriundas da teoria crítica marxista, que hesitaram em relaçào à espacialidade e à temporalidade concretas do capitalismo, uma nova teorizaçào do tempo-cspaço é reivindicada para a teoria social crítica. $\mathrm{O}$ espaço e o tempo deixam de ser considerados como mera representaçào ideológica das sociedades e passam a ser assimilados como a materialidade latente, o substrato da vida social que também é passivel de uma leitura para investigar o comportamento e a estratificação sociais.

Concentrando o olhar na ciência geográfica podemos reconhecer que os conceitos de espaço vital, paisagem, região, gêneros de vida, espaço funcional, classe de área, planejamento regional, espaço social, território e outros têm se constituído nos norteadores paradigmáticos desta ciência. Estes instrumentos analíticos, através de suas aplicações, revelam a natureza de certas visões de mundo e da ciência. Apesar da Geografia ser muito criticada pela falta de aprofundamento nas questōes epistemológicas e pela preocupação excessiva com a aplicação prática e utilitária, é do âmago deste arsenal conceitual que sua episteme irradia.

O conceito de regiào $0^{20}$, por exemplo, foi um dos principais formadores de "escolas" dentro da Geografia. Tanto na sua aceitação, na sua refutação ou nas diversas tentativas de transformação de seu conteúdo significativo. Os geógrafos fisicos e os deterministas ambientais sempre tiveram na "regiào natural" o seu recorte espacial. Já os historicistas somaram à regiào a "paisagem cultural". Estes últimos, por sua vez, refinaram o olhar

\footnotetext{
${ }^{20}$ Sobre a natureza da região há uma discussão considerada clássica de Richard Hartshorne em "The Nature of Geography", Annals of the Association of American Geographers, 29 ( 3 e 4), 1939.
} 
do conceito e da realidade ao trabalharem com regiões especializadas: urbanas, rurais, industriais...

A Revolução Quantitativa do pós-guerra, apoiada no positivismo lógico, considerou "a região a partir de propósitos específicos e da adoção de procedimentos classificatórios das ciências naturais: a regiào passa a ser uma classe de área (...) O pluralismo que já existia até então ganha legitimidade metodológica" (Corrêa, 1994, p.216).

Com a Geografia Critica da década de setenta, novos paradigmas são incorporados. A principal influência é a teoria marxista e a fundamentaçào no materialismo histórico e dialético; mas também as abordagens humanística c cultural se desenvolveram a partir deste período ${ }^{21}$.

Para os primeiros a regiào passa a ser entendida "como a organização espacial dos processos sociais associados ao modo de produção capitalista" (Gilbert, 1988 apud Corrêa, 1994, p.217). Para a geografia humanística e cultural a região é um foco de identificação onde as relações culturais, em grupos e lugares particulares gera um processo de apropriação simbólica do espaço.

Sob a perspectiva materialista o espaço cognitivo ou mental representa a percepção e cognição humanas em relação ao espaço concreto. Essas representações contribuem para a transformação do espaço social, mas é a produção do espaço social - através de idéias e ideologias incrustadas na materialidade - que comanda o processo. Claro que esta perspectiva é crítica - ou pelo menos "desafiadora", em relação tanto às abordagens fenomenológicas/psicológicas quanto às perspectivas essencialmente naturalistas/empiristas. É o espaço social que é, ao mesmo tempo, a ferramenta analítica e parte integrante da instrumentalidade do poder político e econômico.

${ }^{21}$ Como representantes desta abordagem podemos citar J.L.Piveteau, Yi-Fu Tuan, Paul Claval, D.Ley e A.Fremont. 
Para a teoria social crítica dos anos oitenta as estruturas sociais e espaciais unem-se dialeticamente na vida social. Em escalas espaciais diversas, o poder instrumental do Estado e do capital disciplinam desde a vida cotidiana até os processos mais globais.

Giddens é um exemplo importante entre os teóricos sociais contemporâneos que lidam com conceitos carregados de espacialidade, onde os locais diferenciados e hierarquizados, os cenários, as regiões nodais, a territorialidade dào contextualidade à estrutura social.

Outras contribuiçòes empírico-analíticas têm se multiplicado nos recentes estudos sobre regionalizaçào $\mathrm{c}$, com um enfoque macropolítico $\mathrm{e}$ econômico, nos estudos sobre globalização. Todas estas abordagens caminham no sentido de admitir a formação de espaços homogêneos, mas por outro lado, de acentuar a permanência da diferenciação entre regiōes/áreas. Ao mesmo tempo em que a economia mundial e a globalização tendem para a homogeneizaçào, elas acentuam diferenças espaciais num complexo processo de fragmentaçào/articulaçào.

Assim, a divisão territorial do trabalho, as especializações produtivas, as estruturas sociais, culturais e políticas espacialmente variáveis e específicas são, ao mesmo tempo, dependentes de processos gerais/universais. Novamente o conceito de regiào se torna necessário, não para acentuar o "excepcionalismo regional" que pressupunha a idéia de unicidade ("uniqueness"), mas para servir como mediação entre o universal e o singular, o autônomo e o dependente, o micro c o macro (Corrêa, 1994, p.221-22).

\section{O URBANO E SEUS ESPAÇOS}

A partir das décadas de sessenta e setenta surgem duas vertentes principais no sentido de espacializar a teoria social. De um lado, surgem estudos urbanos oriundos de diversas disciplinas; de outro, estudos sobre a reorganização do espaço urbano mundial com ênfase na estratégia do capi- 
talismo para a administração da crise e acumulação de capital. Este último enfoque coloca a cidade como ponto estratégico da reprodução da sociedade capitalista no processo de trabalho, na troca de mercadorias e no padrão de consumo.

Segundo Soja (1993) a problemática urbana e seus estudos sobre a habitação, planejamento, meio ambiente, espaços públicos e outros estudos urbanos tópicos se desenvolveram e proliferaram, separando-se das interpretações sobre o desenvolvimento regional $\mathrm{e}$ internacional. Embora ambas fossem oriundas do marxismo, a segunda abordagem passou a desenvolver teorias sobre o desenvolvimento/subdesenvolvimento tendo como inspiração as obras de Mandel $(1963,1975)$. Este último afirmava que o desenvolvimento espacialmente desigual era tão importante para o capitalismo quanto a exploração do trabalho. Ele fez, ao mesmo tempo, uma periodizaçào e uma espacialização da economia macropolítica do capitalismo contemporâneo.

Sob esta mesma influência também surgiram estudos neo-marxistas a partir da década de setenta, retomando as análises sobre centro-periferia, subdesenvolvimento/dependência, e sobre a acumulação do capital, agora em escala global.

A perspectiva marxista recuperou o conceito de região, associandoo as relações de produção e a organização sócio-espacial dos processos capitalistas e das práticas específicas de classe. As análises privilegiadas recaem sobre a divisão social do trabalho, a acumulação de capital, a reprodução da força de trabalho e dos processos políticos e ideológicos. O enfoque culturalista, associado ou não ao enfoque marxista, também atentou para a região, mas enfatizando a apropriação simbólica de determinados espaços por grupos sociais específicos, num processo definidor de identidade (Corrêa, 1994, p.217).

Como nos lembra Corrêa (1994), é importante frisar que o debate sobre regiões não elimina a importância do debate sobre globalização; ao contrário, são análises complementares. No processo de globalização, que 
emergiu a partir da Segunda Guerra Mundial, associado ao capitalismo industrial, o mundo foi simultaneamente unificado e dividido e os espaços relativamente autônomos que ainda sobreviviam passaram a depender de processos gerais e universais. Assim, a globalização implica um imbricado processo de fragmentaçào/articulaçào. A fragmentação é representada na divisào territorial de especializaçòcs produtivas e especificidades naturais, sociais, culturais e políticas. A articulação é representada por fluxos variados que integram os espaços diferenciados.

Dois conceitos são importantes para a interpretação deste processo: rede c território. Sem entrar aqui num aprofundamento teórico sobre a natureza destes conceitos, vale lembrar que muitos autores têm recorrido a eles como ferramentas analíticas. Garnier (1994, p.305) nos lembra que:

\begin{abstract}
"A tese segundo a qual a proliferação das redes de comunicação à grande velocidade estariam a ponto de modificar a própria consistência do espaço não é nova. Desde vinte anos atrás, numerosos pesquisadores pertencentes às diversas disciplinas (geografia, economia, sociologia, planejamento e urbanismo, ciências da comunicação...) já estavam interessados nos efeitos dos progressos fulminantes realizados no domínio dos transportes e sobretudo das NTC na estruturação dos territórios" (1994, p.305).
\end{abstract}

As redes comportam fluxos de toda espécie, rompem barreiras territoriais, encurtam distâncias e possibilitam uma complexidade de relaçòes (econômicas, sociais, políticas, materiais, informacionais, culturais, de transportes e muitas outras). Através das redes a homogeneização global constrói uma fragmentaçào articulada. Os territórios tradicionais, mais relacionados à autonomia, identidade cultural e recursos locais são agora reorganizados para responder às necessidades de um sistema global. As redes funcionam como mediadoras entre o universal da globalização e o singular das especificidades do território.

Levy (1992) trata destes conceitos e propõe o conceito de "cidademundo" para compreender a complexidade do espaço social no mundo Temáticas, Campinas, 4(7):191-238 jan./jun. 1996 
contemporâneo. Para ele esta análise possibilita compreender a atual organizaçào geopolítica, a economia-mundo e a distância cultural. A dimensão espacial, tida como uma das dimensões do social "corresponde a uma realidade universal, a luta dos homens contra a distância", distância que separa as sociedades e, ao mesmo tempo, é o seu princípio de organização.

Guattari (1984 e 1985), numa leitura mais ousada e menos esquemática, analisa a organização do espaço, ou o espaço produzido por determinada sociedade, como um dado fundamental para a caracterização do poder nesta mesma sociedade: Para ele "a ordem capitalista produz uma subjetividade própria, subjetividade essa que determina constrangimentos a nível espacial" (1985, p.109)

Ele também contrapõe dois conceitos muito ricos para avaliar a realidade contemporânea: os espaços lisos e os territórios existenciais. "Um espaço liso - segundo Guattari - é um espaço desterritorializado, aonde não há mais os mesmos tipos de circunscrições ou delimitações por emblemas étnicos ou religiosos, por exemplo" (1985, p.112). Enquanto o alisamento dos espaços leva a destruição dos territórios existenciais, a emergência de novos territórios existenciais pode representar um exemplo de insubmissão às arquiteturas disciplinares.

"Os territórios estariam ligados a uma ordem de subjetivação individual e coletiva e o espaço estando ligado mais às relações funcionais de toda espécie. O espaço funciona como uma referência extrínseca em relação aos objetos que ele contém. Ao passo que o território funciona em uma relação intrinseca com a subjetividade que o delimita. A partir daí, dá para colocar uma série de questões. Como é que se pode fazer um território num certo tipo de espaço ou inversamente, como no decorrer da história ou por ocasião de algum procedimento atual a gente desterritorializa territórios existenciais, distendendo-os em espaços lisos" (Guattari, 1985, p.110). 
Os processos de territorializaçào/desterritorializaçào/reterritorializaçào do capitalismo têm gerado reflexòes importantes no âmbito das ciências sociais. A cidade - modelo inspirador destas análises - expressa, por meio de signos e símbolos, o local e o global. Os territórios-fragmentos da cidade articulam-se c colocam-se em conflito com o espaço global.

Para Harvey, a diminuiçào de barreiras espaciais, ao contrário do que alguns autores previam, possibilita a exploração de "minúsculas diferenciaçòes espaciais" por capitalistas, e aumenta ainda mais a nossa sensibilidade à diferenciação espacial. Em meio a homogeneização do hiperespaço há uma produçào de lugares diferenciados ativando a competição entre localidades, cidades, regiões e naçòes. Para ele, este paradoxo é central na análise espacial da sociedade contemporânea.

\begin{abstract}
“(...) quanto menos importantes as barreiras espaciais, tanto maior a sensibilidade do capital às variações do lugar dentro do espaço $\mathrm{e}$ tanto maior o incentivo para que os lugares se diferenciem de maneiras atrativas ao capital. O resultado tem sido a produção da fragmentação, da insegurança e do desenvolvimento desigual efêmero no interior de uma economia de fluxos de capital de espaço global altamente unificado" (1992, p.267).
\end{abstract}

Assim como a modernidade contemporânea entrelaça o tradicional ao moderno (e ao pós-moderno?), o movimento de desterritorialização provoca uma nova reterritorializaçào. $\mathrm{Na}$ experiência cotidiana multiplicamse as intersecções e as ambigüidades. "Assim, a fixação de fronteiras políticas pode ser apenas uma escala dentro da rede da hierarquia econômica verticalizada. Ao mesmo tempo, as redes da economia capitalista podem ser forçadas a se adaptar a territorialidades onde a coesão político-cultural local consegue impor sua especificidade". (Haesbaert, 1993, p.16)

Toda esta gama de conceitos tem tornado possivel uma releitura sobre a importância dos mecanismos espaciais tanto para a experiência individual, para a açào social, como para a nova reorganização politicoeconômica do capitalismo contemporâneo.

Temáticas, Campinas, 4(7):191-238 jan./jun. 1996 
Poderíamos ainda citar outros autores, como Galtung (1979) por exemplo, que ao analisar questões sobre desenvolvimento, ambiente e tecnologia chega a conclusão que há uma "cosmologia social do ocidente" operando nas relações com o espaço, tempo, conhecimento e nas relações entre os homens e destes com a natureza a partir de falsas premissas. Para ele, há uma "estrutura cognitiva do capitalismo ocidental" que confere legitimidade a hierarquia intrínseca: o centro, o topo da pirâmide, a periferia... cada conceito com seu correspondente ao nivel social, econômico, cultural, espacial, tecnológico. Do ponto de vista do sistema dominante (Alphaestrutura, ligada ao super ciclo global, que o autor contrapõe à Beta-estrutura, relacionada a contextos locais) esta estrutura é vista como estrutura normal/natural. As estruturas alternativas baseadas na igualdade, autonomia, solidariedade, participação e integração são vistas como ameaças ao sistema.

Da década de oitenta para cá o espaço contemporâneo foi tratado em várias perspectivas e escalas diferentes, desde as práticas da vida cotidiana até uma nova visão geopolítica da divisão global do trabalho. Os debates sobre a transição da modernidade espacializaram as transformações econômicas, sociais, culturais e politicas mapcando as paisagens local, regional e global e contextualizando as particularidades e universalidades da nova restruturação capitalista.

Podemos concluir este primeiro mapeamento com Santos (1991, p.63-64), para o qual a produção espacial e o significado das representações sociais contidas no espaço adquirem cada vez mais importância analítica dentro das ciências humanas.

"O espaço parece, pois, transformar-se no modo privilegiado de pensar e agir o fim do século. Assim sendo, é de pensar que as representações sociais do espaço adquiram cada vez mais importância e centralidade analíticas. Os nossos próprios tempos e temporalidades serão progressivamente mais espaciais. É comum identificar em nossas trajetórias pessoais a sucessão do tempo da familia, da escola, do trabalho. Foi em atenção a essa sucessão 
que se constituíram muitos dos ramos da sociologia e de outras ciências sociais (...) Começamos a ver que cada um destes tempos é simultancamente a convocação de um espaço especifico que confere materialidade própria as relações sociais que nele tem lugar. A sucessão de tempos é também uma sucessão de espaços que percorremos e nos percorrem, deixando em nós as marcas que deixamos neles."

\section{O Debate Pós-Moderno}

É dificil traçar um panorama expondo onde e como a teoria social contemporânea aproximou-se da perspectiva espacial. Enquanto o marxismo ocidental contemporâneo foi subdividido em perspectivas variadas, a própria realidade econômica, política c social do capitalismo ocidental, a partir da década de setenta, foi objeto de transformações radicais estimulando um debate vigoroso sobre o fim da modernidade (Lyotard, 1979), sobre um novo período de compressão tempo-cspaço (Harvey,1992) e de uma multiplicaçào do prefixo "pós" na tentativa de explicar a complexização da realidade contemporânea em várias esferas, alertando para uma quebra de continuidade rumo a uma reflexào renovada.

Depois de análises "pós-historicistas", focalizando a própria teoria social, e análises "pós-fordistas", focalizando a transição do capitalismo para o regime de acumulação flexível, surge um discurso abrangente sobre a "pós-modernidade", envolvendo um novo movimento cultural e ideológico.

Agora, de forma mais eloqüente, a lógica espacial ganha destaque. Jameson exemplifica bem esta colocação:

"O espaço pós-moderno (ou multidimensional) não é simplesmente uma ideologia ou uma fantasia cultural, mas tem uma realidade histórica (e sócio-econômica) autêntica, como terceira grande expansão original do capitalismo no globo (depois das expansões anteriores do mercado nacional e do sistema imperialista 
mais antigo, cada uma das quais teve sua própria especificidade cultural e gerou novos tipos de espaço apropriados à sua dinâmica). (...) Não podemos retornar a práticas estéticas elaboradas com base em situações e dilemas históricos que já não nos pertencem (...) a concepção do espaço aqui desenvolvida sugere que um modelo de cultura politica adequado a nossa situação terá, necessariamente, que levantar questões espaciais como sua preocupação organizadora fundamental." (Jameson, 1984, p.88-9, apud Soja, 1993)

Mesmo se não concordarmos que a pós-modernidade é fruto da terceira grande expansão do capitalismo, como afirma Jameson; ou que ela seja uma condição das transformações para o capitalismo mais flexível, não há mais como se esquivar do debate sobre as transformações da modernidade.

A construção do discurso pós-moderno, alicerçada no âmbito da arquitetura e da arte na década de setenta, envolve, atualmente, várias esferas da vida moderna. Enquanto a arquitetura moderna (que nasceu do organicismo e do racionalismo) eliminou as arquiteturas locais num esforço totalitário, adequou a arte à modernização da sociedade e fez a forma predominar esvaziando o conteúdo de significados; os pós-modernos atacam a "irracionalidade" da modernização no mundo cotidiano, a homogeneização dos estilos e costumes e o modelo estruturante que, ao mesmo tempo em que dizia-se racional e universal, reduzia a multiplicidade de mundos a uma lógica geométrica esvaziada de sentido. $O$ excesso de funcionalidade do espaço construído invadiu o mundo cotidiano e eliminou a possibilidade das diferenças. Com o debate da pós-modernidade o espaço é reconhecido como categoria fundamental na instrumentalização do poder, do controle e das desigualdades sociais.

Mas, se de um lado, os pós-modernos valorizam as diferenças, os múltiplos contextos sociais e a memória histórica; de outro, eles se utilizam de um tradicionalismo superficial das formas a partir de um total liberarismo de estilos. Tentando recuperar o respeito às diferenças, a arquitetura 
pós-moderna combina formas tradicionais, modernas, diferenciadas...mas sem um contexto que as represente. A memória coletiva não é local/nativa, é um recurso selecionado à revelia no "guarda-roupas" da história. Assim, os pós-modernos acabam subvertendo seu próprio projeto com base na diversidade cultural. Ao construírem uma "bricolagem" de formas vazias de sentido (histórico, cultural, social), a arquitetura pós-moderna desterritorializa o espaço.

Tentando superar a contradiçào entre arte e utilidade os pósmodernos da arquitetura separaram, outra vez, forma e função ${ }^{22}$. Mais do que isto, ao impor uma arquitetura-símbolo sem significado para a populaçào em seu contexto, ela repetiu os erros da arquitetura moderna que quis impor uma racionalidade social. Mesmo na arquitetura "simbólica" cuja semiologia vem socorrer a "forma" de sua utilidade prática, e o símbolo é pensado para servir de comunicação entre a arquitetura c o público, parece nào haver nenhuma superação. Os símbolos escolhidos muitas vezes não vem da linguagem formal da arquitetura e sim dos apelos do mercado. Como coloca Ortiz (1992), a arquitetura pós-moderna é crítica com o passado da modernidade, mas conformista com os desafios do presente. Por isto alguns autores parecem concordar que entre o "simbolizar" da pósmodernidade e o "estruturar" da modernidade muitas semelhanças permanecem.

Para Harvey (1992) existe uma relaçào necessária entre a pósmodernidade cultural, a acumulaçào flexível do capital e um novo período de "compressão tempo-espaço". Mas ele adverte: tais mudanças, vistas à luz das "regras básicas de acumulação capitalista", mostram-se mais como um recurso camaleônico do capitalismo do que uma ruptura para uma nova sociedade. Assim, a pós-modernidade é colocada como uma "condição", um referencial inevitável para se pensar a sociedade, mas não uma ruptura.

${ }^{22}$ Que segundo Habermas (1981), foi um dos méritos da Arquitetura Moderna Temáticas, Campinas, 4(7):191-238 jan./jun. 1996 
Se por um lado Harvey considera que o ponto forte do pósmodernismo é ter ressuscitado as diferenças que as metateorias do modernismo haviam extinguido, por outro lado, ele não se ilude: "há mais continuidade do que diferença" (1992, p.111), e a superficialidade das obras, dos projetos e das posturas são testemunhas de que as aparências reivindicam $o$ trono da verdadeira essência dos problemas sociais, econômicos, políticos e culturais. A ética foi substituída pela estética cuja forma sugerida é uma encenação, um espetáculo descomprometido com a função. Harvey aponta que este caminho é um discurso perigoso pois desemboca na estetização da política. Sem medo da analogia histórica ele associa a sensibilidade pósmoderna a um novo interesse pela geopolítica, pela estética do lugar e pela questão da espacialidade. Tudo isto, sempre "no interior de uma economia de fluxos de capital de espaço global altamente unificado" (ibid., p.267).

Ele desenha o perfil do caos urbano representado nas mercadorias, modas, gostos, signos, imagens... manipulados pelo mercado e influenciando as práticas sociais, culturais e o poder de classe. Para Harvey, na era da "acumulação flexível", as imagens como simulacros dominam todos os campos, do econômico ao psicológico, da arte à política, da geografia à arquitetura, do lugar ao espaço globalizado. Harvey se debate entre a identidade social proporcionada pelo lugar e a espacialidade estetizada, fragmentada, superficial e globalizada. Ambas necessárias a uma pós-modernidade esquizofrênica.

Para Habermas (1981) a organização da realidade urbana contemporânea cruza conexões funcionais de dificil tradução, e a linguagem formal da arquitetura não dá conta destas conexões, apenas se submete aos seus meios de representação simbólica. Considerando que a arquitetura moderna respondeu bem às "novas possibilidades técnicas de criação" e às "novas carências qualitativas" do início do século, ele salienta que o problema foi não ter oferecido respostas às questões de "dependência sistêmica dos imperativos da administração planejada e do mercado". Habermas concorda 
com a crítica dos pós-modernos ao que a "Nova Construçào" quis impor sua concepçào à totalidade de estilos $\mathrm{e}$ formas de vida que incluíam múltiplos, complexos e mutáveis mundos da vida, impossíveis de serem enquadrados. Mas, para ele, o erro da arquitetura moderna não foi ter associado forma e funçào, mas ter subestimado que "as sociedades modernizadas" possuem "conexões sistêmicas" que extrapolam a capacidade de medida e de criatividade do planejador. Após a II Guerra o espaço passou a ser organizado não pela arquitetura, mas pelas limitações econômicas e políticoadministrativas.

Por isto Habermas não concorda com o diagnóstico dos arquitetos pós-modernos. Para ele o fracasso não foi da arquitetura, afinal, a mediatizaçào cada vez maior das conexões sistêmicas não configuráveis sobre o mundo da vida é uma questào que não poderia ter sido resolvida no âmbito exclusivo da arquitetura. Ele afirma que,

"os problemas do planejamento urbano não são primariamente de organização espacial, mas de insuficiência gestionária, de represamento e orientação de imperativos sistêmicos anônimos, que interferem nos mundos da vida citadinos e ameaçam-lhes consumir a substância urbana" (1981, p.122).

Isto nos leva de volta à teoria social pois, apesar desta afirmação, ć possível fazer uma leitura da teoria da ação comunicativa de Habermas onde as escalas espaciais estão fortemente representadas. Não nas "construções" modernas ou pós-modernas mas em suas concepções de mundo da vida, onde está presente a participação com significado e conteúdo; e de conexões sistêmicas, invadindo o mundo da vida e impondo sua lógica à esfera da razão comunicativa.

A separação e a dependência recíproca entre estas duas esferas, a colonização do mundo da vida pelo sistema e a necessidade do próprio sistema desta "contingência criadora" nos leva a considerar que a teoria de Habermas, apesar de mais complexa e mais refinada, tem muitas afinidades 
com a escala espacial dos atuais estudos sobre "territórios", "redes" e "globalizaçào".

\section{CONSIDERAÇÕES FINAIS}

Este texto não teve a pretensão de aprofundar questões substantivas sobre a recusa, aceitação ou marginalização da perspectiva espacial na teoria social. Pretendeu apenas fazer um mapeamento preliminar sobre esta questão a partir de importantes contribuições e argumentos de autores que, dircta ou indiretamente, lançaram novas questões sobre a abordagem espacial.

Neste sentido a questão ambiental, que se colocou para a sociedade contemporânea, principalmente a partir da década de setenta, trouxe novos desafios para a realidade, para a ciência e para os poderes políticos e econômicos. $\mathrm{Na}$ tradição científica as problemáticas relacionadas a população, cultura, ambiente, sociedade e outros temas afins vicram sendo tratadas como conhecimentos estanques da realidade, como se este conhecimento parcelado pudesse, em alguma outra dimensão do conhecimento, abarcar a realidade enquanto totalidade.

A questão ambiental, como parâmetro para a análise social, além de desvendar as diversas relações do homem com a natureza, as tecnologias empregadas e as estruturas sócio-econômicas correspondentes, vai mais além da descrição e classificação do grau de satisfação de necessidades humanas, via a apropriação e manipulaçào da natureza e a consequente interferência nos processos ecológicos. A partir do conhecimento das posturas do homem sobre a natureza é possivel compreender suas respectivas organizações sociais e as estruturas cognitivas que as legitimam:

"En el nivel de las formaciones ideológicas mais generales, la problemática ambiental ha significado el requebrajamiento de uno de los dogmas más perdurables desde la tradición judeo-cristiana 
hasta la história del pensamiento occidental moderno, es decir, el de la presencia del hombre en la Tierra como amo de la naturaleza. Tal domínio de la naturaleza no sólo ha aparecido como unacapacidad excepcional de la especic humana para transformar los recursos naturales e incluso para controlar una seria de fenómenos naturales por medio de sus creaciones cientificas $y$ tecnológicas, a su vez ha permitido ocultar las relaciones de explotación del hombre por el hombre que han permitido la apropriacion de la naturaleza y su transformación en riqueza social." (Montes \& Leff, 1986, p.27)

Posturas como esta trouxeram um problema positivo para a ciência: a necessidade de um novo referencial teórico ou, ao menos, a de uma revisão $\mathrm{em}$ antigas fronteiras paradigmáticas. Nesse sentido, a abordagem ambiental teve o mérito de ser a catalisadora de novas propostas de análise da realidade enquanto totalidade. Costa (1992, p.12), ao fazer uma leitura de diversas abordagens teóricas que se inscrevem neste debate, parte do pressuposto de que o "espaço" pode ser a categoria de análise capaz de intermediar esta discussão:

"A hipótese básica a ser proposta para discussão é que o espaço seria o elemento, ou a categoria de análise que teria a capacidade de articular estas diversas vertentes teóricas. Através da análise dos processos de produção e apropriação do espaço em geral (e do urbano em particular, que nos interessa mais de perto) seria possivel fazer a ponte entre um maior nivel de abstração teórica $e$ as realidades concretas".

De volta ao "espaço" podemos dizer que esta categoria, que não é nova na tradição científica, está passando por uma nova leitura em várias ciências. Se o projeto da modernidade subjugou a natureza à dominação humana, também o espaço construído socialmente, enquanto natureza transformada, foi naturalizado a partir de uma visão onde espaço e natureza nada mais são que recursos disponíveis para o projeto da dominação do homem. Hoje não é mais possível pensar o espaço social somente a partir 
de sua materialidade, como um elemento estático da realidade, desprovido de um poder organizador/transformador. Através das representações coletivas de espaços, os grupos sociais podem identificar a si próprios e a sua cultura.

Harvey complementa este debate ao dizer que a questão não é acusar a forma fisica pelos problemas sociais - o que seria um tipo vulgar de determinismo ambiental. Mas é preciso reconhecer no espaço uma categoria analítica muito rica em "representaçòes sociais" a partir das quais interpretamos e agimos no mundo.

Neste sentido, podemos retornar ao "modelos de desenvolvimento" para refletir sobre duas questòes: a primeira é o desafio que a problemática ambiental traz ao planejamento espacial (local, regional e global). A segunda, é este mesmo desafio que coloca para a ciência um questionamento sobre si mesma, seus paradigmas, suas megateorias e sua "divisão disciplinar do conhecimento".

Quanto a primeira questão é possivel dizer que, se por um lado, o avanço da reorganizaçào mundial extrapola fronteiras nacionais, por outro vale dizer que o processo de globalização passa a ser questionado a partir da deterioração dos "modelos de desenvolvimento". Aqui se coloca a questão das realidade locais e suas peculiaridades. $\mathrm{O}$ sistema capitalista ocidental criou uma rede interminável de centros e periferias que possuem a função de propagar e reproduzir a estrutura sócio-econômica e cognitiva do modelo ocidental. A transferência tecnológica transfere também um "modelo de desenvolvimento" que priva certos países, certas localidades de se desenvolverem de acordo com suas próprias necessidades e recursos. (Galtung, 1979)

Criou-se, no mundo ocidental, um modelo para se atingir o desenvolvimento. A propagação deste modelo tem sido, na maior parte das vezes, uma confusão entre meios e fins (Declaração de Cocoyoc, 1974). As realidades locais não contam ou são consideradas nocivas à estabilidade do sistema. 
Mas se o conceito nào é mágico, o planejamento tampouco. Se a ciência está revendo seus paradigmas, pode-se dizer que os próprios detentores do poder para o planejamento/desenvolvimento estão em busca de novos modelos norteadores.

Uma contribuição importante é a necessidade de se deslocar o problema do desenvolvimento do campo estrito da economia, e nesse sentido adentrar no campo da ética e dos valores das reais necessidades humanas, de que parcela da humanidade se trata, qual sociedade, que tipos de ecossistemas envolvem e quais as condições históricas e materiais de realização de um planejamento.

É importante refletir sobre a transferência destes "modelos", sobre estas caricaturas de espaços funcionais, e tentar recuperar, nas peculiaridades locais/regionais as estruturas sociais, econômicas e cognitivas que são próprias a cada sociedade com suas práticas, sua materialidade, suas representações de mundo e sua relação com a natureza. Isto não significa descartar o modelo de desenvolvimento global para dividir o espaço e a sociedade em ilhas isoladas e autônomas. Significa encontrar um equilibrio entre os dois modelos, entre os dois conceitos. Isto é o que prima a questão ambiental.

Em relaçào ao desafio que a questão ambiental coloca para a ciência, algumas questões sào básicas. A primeira é que "há algo crrado com a organizaçào disciplinar do conhecimento" (Daly \& Cobb, 1989). Os excessos de "cientificismos", de modelos abstratos e dedutivos e de especializaçào distanciaram a ciência da realidade concreta/objetiva. A realidade foi fragmentada pela fragmentação do conhecimento, como se este último fosse mais importante que a própria realidade.

Rever fronteiras paradigmáticas, megateorias ou simplesmente romper com a visão dicotômica (sociedade-natureza, principalmente) é um desafio para a ciência neste fim de século. Embora haja uma grande dificuldade de cunho teórico-metodológico devida a extrema especialização dentro 
de cada ciência, a problemática ambiental aponta para a necessidade de um trabalho interdisciplinar.

No mundo ocidental desenvolveu-se um modelo para executar o desenvolvimento que muito se aproxima às críticas que Daly faz sobre a ciência. No fim (lembrando que há uma confusão entre meios e fins) o que importa é o funcionamento do próprio modelo (os instrumentos, a técnica e o conhecimento). A tecnologia (ocidental, industrial, capitalista) está para a realidade assim como esta racionalidade cientifica (ocidental, positiva, linear) está para a ciência. É preciso desmistificar estes modelos, conhecendo-os e construindo uma via alternativa.

O espaço como categoria analítica para a avaliação da problemática ambiental, pode funcionar como um leme orientador para as questões da realidade concreta (do planejamento/desenvolvimento) e para o processo de conhecimento (interdisciplinaridade).

O espaço, enquanto categoria analítica, pode tornar-se fundamental para a análise das diversas inter-relações entre as formas sociais, a política, o modo de produção, as formas de apropriação da natureza, os sistemas cognitivos, o espaço construído c a natureza. Muitos podem questionar se esta categoria se presta a tanto. Isoladamente não. Seria o retorno ao "fetichismo" e ao "determinismo". Mas no âmbito da teoria social e da nova problemática ambiental, ele é uma ferramenta interpretativa que não pode mais ser negligenciada.

ABSTRACT: This paper is a prelliminary of the most important in the human sciences, towards a better understanding of the spatial category - while a science object and analitical tool - in the context of systematization of scientific thinking and also some vius of the word wich drives to a modernity project and it's contemporary developments.

KEYwoRDS: space, time, modernity, globalization, environment, social theory. 


\section{REFERÊNCIAS BIBLIOGRÁFICAS}

BOTTOMORE, T. e NISBET, R. (orgs.) História da Análise Sociológica, Rio de Janeiro: Zahar, 1980.

BURKE, P. A Escola dos ANNALES (1929-1989): A Revoluçào Francesa da Historiografia, São Paulo: Ed. da UNESP, 1991.

BURTON, I. A Revolução Quantitativa e a Geografia Teorética, Boletim de Geografia Teorética, V.7 (13, p.63-84), 1977, Ageteo-Rio Claro, S.P.

BUTTIMER, A. O Espaço Social Numa Perspectiva Interdisciplinar, in SANTOS \& SOUZA (org.) O Espaço Interdisciplinar, São Paulo: Nobel, 1986.

CASTELLS, M. A Questão Urbana, Rio de Janeiro: Paz e Terra, 1983 (1 ${ }^{\circ}$ ed. 1977).

CORRÊA, R.L. Redes, Fluxos e Territórios: Uma Introdução in Anais do 30 Simpósio Nacional de Geografia Urbana, R.J./A.G.B, 1993.

(1994) "Regiào: Globalizaçào, Pluralidade e Persistência

Conceitual" in Anais do 5 Congresso Brasileiro de Geógrafos (AGB), Curitiba-PR.

COSTA, H.S.de M. Questão Ambiental, Populaçào e Espaço Urbano: Em Busca de Um Novo Paradigma? Anais da ABEP, Vol. III, 1992.

DALY, H.E. e COBB, U.B.Jr. For the Common Good Redirecting the Economy Toward Community, the Environment and Sustainable Future, Boston, Beacon Press, Green Print, 1989.

DURKHEIM, Émile As Formas Elementares de Vida Religiosa (o sistema totêmico na Austrália), Sào Paulo: Ed. Paulinas, 1989.

. Sociologia e Filosofia, Rio de Janeiro: Forense Universitária, 1970. - As Regras do Método Sociológico, Sào Paulo: Companhia Editora

Nacional, $1990\left(1^{2}\right.$ ed. 1893$)$

FOUCAULT, M. Questions on Geography in GORDON (org.) Power, Knowledge: Selected Interviens and Other IVritings, 1980. . Of Other Spaces, Diacritics, 16, 1986. 
GALTUNG, J. Development, Environment and Technology: Towards a Technology for Self-Reliance, New York: United Nations (United Nations Conference on Trade and Devclopment), 1979.

GARNIER, J.P. L'Ecologisme ou la Fétichisation de L'Espace-Temps in Economies_et Sociétés (Série "Études de Marxologie"), № 30-31, 6/7, 1994, p.299-321.

GUATTARI, F. Espaço e Poder: A Criação de Territórios na Cidade in Espaço $e$ Debates, Ano 5, n.16, 1985.

. Micropolitica - Cartografias do Desejo, Petrópolis: Ed. Vozes, 1986.

HABERMAS, J. Modernidade - Um Projeto Inacabado in Um Ponto Cego no Projeto Moderno de J.Habermas (Arquitetura e Dimensão Estética Depois das Vanguardas), Edit.Brasiliense, 1980.

- Arquitetura Moderna e Pós-Moderna in Novos Estudos Cebrap/1987, N. 18, 1981.

HAESBAERT, R. O Processo de Des-Territorialização e a Produção de Redes, Territórios e Aglomerados, Versão Preliminar, R.J, 1983.

HARVEY, D. A Condição Pós-Moderna, São Paulo: Loyola, 1982.

HORKHEIMER, M. e ADORNO, T. Conceito de Iluminismo in Col. Os Pensadores, (Textos Escolhidos) Ed.Abril Cultural, p.98-124, 1980.

JAMESON, F. Post-Modernism or the Cultural Logic of Capitalism, Nen Left Revien, n.146, 1984.

KUHN, T. A Estrutura das Revolugõos Cientificas, São Paulo: Edit. Perspectiva, 1990.

LACOSTE, Y. Os Paises Subdesenvolvidos, SP: Perspectiva, 1983.

. A Geografia - Isso Serve, em Primeiro Lugar, Para Fazer a Guerra,

Campinas: Edit. Papirus, 1988.

LEFEBVRE, H. La Production de L'Espace, Paris: Anthropos, 1974.

. Reflections on the Politecs of Space in Antipode, n.8, 1976.

LĖVY, J. et al. Le Monde: Espaces et Systèmes, Paris, FNSP/Dalloz, 1992. 